\title{
The Intercultural Sensitivity of Chilean Teachers Serving an Immigrant Population in Schools
}

\author{
Karla Morales Mendoza ${ }^{1 *}$ (D) , Susan Sanhueza Henríquez² (1), \\ Miguel Friz Carrillo ${ }^{3}$ (D) , Paula Riquelme Bravo 4 (1) \\ ${ }^{1}$ Centro de Estudios Migratorios e Interculturales, Universidad Católica del Maule, Chile \{kmorales@ucm.cl\} \\ ${ }^{2}$ Centro de Estudios Migratorios e Interculturales, Universidad Católica del Maule, Chile \{ssanhueza@ucm.cl\} \\ ${ }^{3}$ Facultad de Educación y Humanidades, Universidad del Bío-Bío, Chile \{mfriz@ubiobio.cl\} \\ ${ }^{4}$ Facultad de Educación, Universidad Católica de Temuco, Chile \{riquebra@uct.cl\} \\ Received on 14 March 2016; revised on 11 April 2016; accepted on 15 April 2016; available online 15 August 2016; published on 15 \\ January 2017 \\ DOI: 10.7821/naer.2016.8.173 \\ (ख) [W-NC-ND
}

\begin{abstract}
The objective of this article is to evaluate the intercultural sensitivity of teachers working in culturally diverse classrooms, and to analyse differences in intercultural sensitivity based on the gender, age, training (advanced training courses), and intercultural experience of the teachers. A quantitative approach with a comparative descriptive design was chosen. The Intercultural Sensitivity Scale was used, composed of 24 statements, which were responded to by 50 teachers. The results show that teachers possess moderate intercultural sensitivity and that the highest rated competencies are trust and attention to communication.
\end{abstract}

KEYWORDS: CULTURAL DIVERSITY, AFFECTIVITY, INTERCULTURAL EDUCATION, IMMIGRATION

\section{INTRODUCTION}

To begin, we would like to conceptualize cultural diversity, particularly in the context of Chile - the country in which the study was carried out.

We understand a system of beliefs to be the values, customs and behaviours, shared by members of a society, which are built upon a relationship with others. In this way, intercultural competency should be understood as the interaction between people who possess different emotional, cognitive or behavioural orientations and who, therefore, possess an alternative worldview. The most common representative traits are those relating to nationality, race and religion. This interaction does not always act at the same level, so the degree with which people express their proximity to a group will be a manifestation of their intercultural competence. Moreover, "cultural diversity" refers to the different meanings or interpretations that different groups give to their experiences in

\footnotetext{
${ }^{*}$ To whom correspondence should be addressed:

Universidad Católica del Maule, Facultad de Educación

Séptima Región del Maule, Avenida San Miguel 3605

Talca-Chile, 3480112
}

Chilean society. These groups include: a) indigenous natives who were living in what is now called Chile upon the arrival of the Spanish; b) the miscegenation of natives and Spaniards, which forms the basis of the profile and ethnic fabric of the majority of the Chilean people; c) the immigrant groups who later came to the country and subsequently mixed with the Chilean population; and d) the new immigrants who have arrived in the last few decades and who continue to come to Chile to make a new home for themselves (Barra, 2007). For this study, we have focused on the last of these culturally diverse groups: the so-called "new immigrants" or "foreigners".

Chile has a population of 18 million, of which the number of legal immigrants is around 440,000. The predominant group is from Peru, although immigration from Caribbean nations such as Haiti and The Dominican Republic is growing. Also interesting is the immigration of emerging groups from countries in the Organization for Economic Cooperation and Development (OECD); here Spain is in the lead (4,842 households), followed by the USA $(3,773)$, Mexico $(2,300)$, France $(2,104)$, Germany $(1,769)$ and South Korea $(1,001)$. It is true that when compared to South American immigration, the extent of OECD immigration is minimal - just $10 \%$ of the total - but this situation confirms Chile's place in the international context (Departamento de Extranjería y Migración del Ministerio del Interior de Chile, 2015).

This scenario puts before Chile a series of challenges linked to both the country's ability to host and provide opportunities for immigrants to develop their lives within our borders, and its capacity to manage the coexistence of Chileans and immigrants. This last task can largely be addressed through public education policy. One aspect that concerns the Ministerio de Educación is the integration of immigrant students, the educational response they receive and the relationships established in the classroom between foreign and native students.

The education of immigrants is mainly carried out through the public education system. According to official figures from the Ministerio de Educación, the current enrolment of immigrants in basic education is 14,186 students, with 3,688 of these in secondary education (Ministerio de Educación de Chile, 2014). 
The regions with the largest immigrant school populations are Metropolitana, Antofagasta and Tarapacá; however, all the country's regions have foreign students in their classrooms.

This configuration demands special sensitivity and specific training to enable teachers to address cultural diversity. The role of the teacher determines the coexistence of students in the multicultural classroom. Evidence exists (Alonso \& Martínez, 2011) that the activities and beliefs of teachers have an effect on educational practice, not only in terms of the academic success of students, but on the state of wellbeing, or lack of it, in the school. Creating a classroom climate that is suitable for the sort of coexistence in which processes of teaching and learning can take place requires a teacher who views him or herself as a subject with something to offer towards the integration of cultural minorities, favouring intercultural competencies (Sanhueza, Cardona, \& Friz, 2015).

Intercultural communicative competency is defined as the ability to negotiate cultural meanings and carry out effective communicative behaviours (Vilà, 2010). It consists of cognitive, behavioural and emotional dimensions.

Cognitive intercultural communicative competency is the knowledge, understanding and awareness of both one's own cultural and communicative elements and those of others, thus promoting effective communication.

Behavioural intercultural communicative competency is the collection of verbal and non-verbal abilities that demonstrate a behavioural adaptation which is conducive to appropriate and effective communication in a given context.

The emotional dimension is called intercultural sensitivity and it refers to the ability to communicate satisfactorily with people from other cultures. This ability is taught so that children and young people can learn to perceive specific concepts, ways of thinking, feeling and acting of a group that is culturally different.

It is clear from the definitions above that communication is a process of negotiation with other cultures, and that it involves establishing comparisons between these cultures. The objective is to go beyond peripheral and superficial understanding, advancing instead towards the comprehension and recognition of what is different - a process that should be a common practice in the multicultural classroom.

Vilà (2010) provides some criteria for effective communication, such as the need to establish a certain cultural proximity; some degree of knowledge and conscience when considering other cultures and your own; an interest in learning from other cultures; and the capacity to empathize with others. In the same vein, Chen and Starosta (2000) identify trust, involvement, attention and the ability to enjoy intercultural interaction as components of intercultural sensitivity, while McCroskey and Neuliep (1997) build on the concept of Intercultural Communication Apprehension, defined as the fear or anxiety associated with real and anticipated interactions with people from different groups -particularly along cultural, ethnic and/or racial lines.

Moreover, emotional competency also involves resources implicit in overcoming negative emotions and enhancing those positive emotions which promote intercultural communication. From this perspective, the level of involvement involves interacting in a way that is both significant and motivated in situations of intercultural communication. The level of respect for the cultural differences of people involved in intercultural communicative encounters is another key element in the development of positive attitudes that benefit intercultural communication.
Some emotional responses that facilitate intercultural communication are trust; an enjoyment of intercultural interaction; and the attention commonly paid during intercultural communicative contact $-\mathrm{a}$ basic attitudinal element for denoting interest and motivation when listening to an interlocutor from a different culture.

\subsection{Teacher training in cultural diversity}

Stefoni (2011) points out that given Chile's relatively recent status as a country with immigration, and the consequent shortage of studies on the condition of this new population, the difficulties in the school environment become more palpable. However, on the level of public policy there is an ever-greater awareness of the fact that the multicultural society in which we live provides new challenges, related to both education and teacher training.

It is very common to hear from teachers who suffer through problematic and uncomfortable situations when attempting to teach in multicultural contexts. This scenario often leads, in turn, to the reluctance, refusal and disinterest of students. While there are a variety of reasons for this problem, a lack of training models adapted to cultural differences is one of the mostdocumented. Calatayud (2006) notes that teachers are insufficiently trained in meeting the challenges posed by the increasing levels of immigration and the growing numbers of students from different cultures in their classrooms.

Another study carried out by Medina and Domínguez (2006) with student teachers concluded that these display an attitude of acceptance towards people who are culturally different, even seeing them as a stimulating their professional development. However, the teachers' lack of preparation leads them to make mistakes when developing the idea of "a real problem to overcome".

Teacher training programmes should include actions aimed at changing the beliefs of student teachers regarding cultural diversity, promoting the acceptance of different cultures and encouraging different styles of teaching and learning.

For Sanhueza, Granada and Bravo (2012) the conceptions of teachers usually reveal themselves through implicit theories, by way of which they try to explain their actions; hence the need for teacher training programmes which modify the attitudes and behaviours of teachers from the beginning. Díaz-Aguado (2006) notes that teachers can and should eliminate discriminatory practices as soon as these are identified.

In the same vein, Chiner, Cardona and Gómez (2015) studied the beliefs of teachers regarding diversity, as well as the teachers' levels of sensitivity regarding a number of related subjects. The results revealed a highly positive attitude towards diversity in all its dimensions (cultural, linguistic and social), especially in the personal sphere.

The intention behind these studies is to highlight the personal and professional position of teachers who base their actions on their practical knowledge and experience. If these aspects are not considered in a training model, then stereotyped and negative attitudes may be reinforced.

For Alvites and Jiménez (2011) the teacher is crucial to reproducing or overcoming discrimination, prejudice and stereotypes. This means that the teacher is a key player for achieving the goals - in terms of knowledge, attitudes and behaviour - being sought.

As we have stated, an attention to social, cultural and linguistic diversity constitutes the primary preoccupation of 
teachers. For García (2005), the intercultural competencies of teachers include the skills that should be acquired in terms of knowledge, affectivity and practical activities. Therefore, the acquisition of some authentic intercultural communicative competencies seem essential for a teacher to perform his or her duties in a democratic society.

Quintriqueo y colaboradores (2014) propose an intercultural education based on comparing the knowledge and experience of people from different cultural spheres. This requires building an awareness built on dialogue between cultures. In this approach, intercultural education in teacher training aspires to prepare subjects who can discover and recognize cultural differences, as well as understand how the cultures relate. This involves valuing the identity and educational contents and goals of "others" in order to educate, fostering understanding and dialogic competencies in both native students and in those who are culturally different. For Medina, Rodríguez and Ibañez (2004), the challenge involves training teachers to advance an intercultural society by facilitating interaction with other cultures through knowledge of the most representative values of these cultures: their education system, study plans, methods of working in class and relationship style, amongst other things.

As can be seen, the development of intercultural communicative competencies is a relevant task for teachers because of the impact that it can have, not just on immigrant children and youth, but also on the educational system as a whole. In this context we consider our objective to be the evaluation of the intercultural sensitivity of teachers working in culturally diverse classrooms, and the analysis of differences in intercultural sensitivity based on gender, age, training (advanced training courses) and the intercultural experience of teachers (having worked with students from diverse cultural backgrounds).

\section{METHOD}

\subsection{Focus and design}

The focus of the research is quantitative (Hernández, Fernández, \& Baptista, 2010) utilising quantifiable information to describe or explain the sensitivity of teachers working with immigrant children and young people in Chile. The chosen design was nonexperimental and descriptive ex post facto by survey - an appropriate design for poorly documented phenomena. Carrying out the research via survey enabled us to collect data specifically and accurately with the aim of learning about the attitudes that shape positive or negative emotional reactions towards intercultural communication. An attitude is a state of psychological disposition, acquired or organized through experience, which incites an individual to react in a characteristic manner when faced with certain situations. In other words, if the person makes an internal evaluation that is positive and/or pleasant, then their attitude towards this object will be positive and favourable (Sanhueza, 2010) On the other hand, if the evaluation is negative, the attitudes towards others will be unfavourable. Social attitudes do not develop at the poles, but instead move between them. That is why it was important to use a Likert scale, which makes it possible to infer the level of intercultural sensitivity of subjects from their verbal and non-verbal responses.

\subsection{Context and participants}

The Metropolitana and Valparaíso regions, where the study was carried out, are in central Chile and both have a large immigrant population. The children and young people in these areas attend public, private or subsidized schools. The most highly represented group is Peruvian. The sample, which was intentional and subject to availability (Cardona, 2002) is comprised of 50 teachers from five schools, principally at primary level (98\%). The schools have an average of $7 \%$ immigrant students. A high percentage of teachers surveyed possess graduate or postgraduate degrees (66\%) in education. However, 88\% reported having no specific training in the area of intercultural education. 92\% stated that they had over 5 years' experience of working with immigrant students. The subjects' ages ranged from 26 to 55, the average being 48. Women (70\%) outnumbered men (30\%). All teachers responding to the survey were Chilean.

\subsection{Variables and instruments}

Chen and Starosta's (2000) Intercultural Sensitivity Scale was used for this study. This scale was especially designed to evaluate the emotional responses of university students. However, research has also been carried out at other educational levels, such as primary and secondary. The survey contained 24 statements, to which subjects were asked to reveal their level of agreement on a 5-point Likert scale, graded as follows:

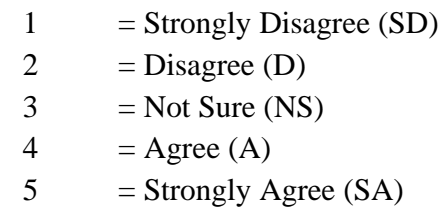

As can be seen, the smallest possible score on the scale is 24 points (showing a negative attitude) and a maximum of 120 points (displaying a very favourable attitude). 72 points would reveal an indifferent or indecisive attitude (Osma, Crespo, \& Fermoselle, 2010). Below, we present a summary of the psychometric properties of the instrument derived from previous studies:

Table 1. Psychometric properties of the Intercultural Sensitivity Scale.

\begin{tabular}{lllc}
\hline \multicolumn{1}{c}{$\begin{array}{c}\text { Study/ } \\
\text { author }\end{array}$} & Participants & Characteristics & $\begin{array}{c}\text { Intercultural } \\
\text { Sensitivity } \\
\text { Scale }\end{array}$ \\
\hline $\begin{array}{l}\text { Chen and } \\
\text { Starosta } \\
\mathbf{( 2 0 0 0 )}\end{array}$ & $\begin{array}{l}\text { University stu- } \\
\text { dents (N=750)2 }\end{array}$ & $\begin{array}{l}\text { Number of } \\
\text { statements } \\
\text { Reliability } \\
\text { Number of } \\
\text { factors }\end{array}$ & 24 \\
\hline De Santos & University busi- & $\begin{array}{l}\text { Number of } \\
\text { statements }\end{array}$ & .86 \\
(2004) & $\begin{array}{l}\text { ness students } \\
\text { (N=47) }\end{array}$ & $\begin{array}{l}\text { Number of } \\
\text { factors }\end{array}$ & 23 \\
\hline Vila (2005) & $\begin{array}{l}\text { Secondary school } \\
\text { students }\end{array}$ & $\begin{array}{l}\text { Number of } \\
\text { statements }\end{array}$ & .82 \\
& & $\begin{array}{l}\text { Reliability } \\
\text { Number of } \\
\text { factors }\end{array}$ & 22 \\
\hline Sanhueza & $\begin{array}{l}\text { Primary and } \\
\text { secondary school } \\
\text { students (N }=\end{array}$ & $\begin{array}{l}\text { Number of } \\
\text { statements } \\
\text { Reliability } \\
\text { Number of }\end{array}$ & .84 \\
& 1.163) & factors & 5 \\
\hline
\end{tabular}


As can be observed, this instrument has been applied to different groups, sociocultural contexts and areas such as education and business.

For the present study, the decision was taken to maintain the 24 statements (Chen \& Starosta, 2000), making use of Vilà's idiomatic adaptation (2005). As can be seen in Table 1, Vilà only identifies 22 statements, so we have carried out the idiomatic adaptation of the remaining two. The internal consistency of the instrument generates a Cronbach alpha coefficient of reliability of 0.91 . The measurement of sample adequacy was acceptable $(\mathrm{KMO}=0.80)$ and Bartlett's spericity test was statistically significant: $\mathrm{x} 2(197, \mathrm{~N}=50)=1141, \mathrm{p}=$ 0.000 . The analyses confirm the five initial factors explaining the $62.5 \%$ variance in the emotional responses of teachers when faced with cultural differences.

\subsection{Procedure and data analysis}

The instrument was applied by a previously trained interviewer who informed teachers about the objectives and general characteristics of the study. He provided them with information about the researchers and asked them for their cooperation, stressing the fact that their participation was voluntary, confidential and anonymous. After obtaining written consent, the 40-minute survey commenced. All participants were given the opportunity to ask questions if they had any doubts.

Data analysis was carried out using the statistics program SPSS 18.0 and the techniques used were mainly descriptive statistics of central tendency (mean) and dispersion (standard deviation) plus a calculation of frequencies and percentages. Student's t-test and ANOVA were both used for the comparison of groups. It is important to note that for data analysis the score of inverse or negative statements $(2,4,6,8,13,17,20$ and 22) was inverted.

\section{RESULTS}

The first dimension evaluated was the level of engagement in interaction with immigrant groups (Table 2). The results show that in general terms these teachers do become engaged in a communicative relationship with people who are culturally different. This means that they like to interact with other cultures $(70 \%)$ and try to gather as much information about them as they can (64\%). Perhaps the most obvious difficulty expressed in the data has to do with non-verbal communication, as only $42 \%$ develop this skill properly.

Table 2. Descriptives "involvement in interaction"

\begin{tabular}{lrrrrrrr}
\hline \multicolumn{1}{c}{ Statement } & $\boldsymbol{M}$ & $\boldsymbol{S D}$ & NS & SD & D & A & SA \\
\hline $\begin{array}{l}\text { I like to interact with people } \\
\text { from other cultures }\end{array}$ & 4 & 0,4 & 0 & 0 & 0 & 30 & $\underline{70}$ \\
\hline $\begin{array}{l}\text { I think I have the skills to } \\
\text { interact with people from } \\
\text { different cultural back- } \\
\text { grounds }\end{array}$ & 3 & 0,9 & 4 & 4 & 0 & 34 & 58 \\
\hline $\begin{array}{l}\text { I often become exasperated } \\
\text { when dealing with people } \\
\text { from other countries }\end{array}$ & 3 & 1,0 & $\underline{10}$ & 4 & 4 & 16 & 66 \\
\hline $\begin{array}{l}\text { It is easy for me to under- } \\
\text { stand the non-verbal messag- } \\
\text { es of people from different } \\
\text { cultures }\end{array}$ & 3 & 0,9 & 4 & 2 & 8 & 44 & $\underline{42}$ \\
\hline $\begin{array}{l}\text { I tend to avoid situations that } \\
\text { require me to interact with } \\
\text { people from other cultures }\end{array}$ & 3 & 1,0 & $\underline{10}$ & 6 & 2 & 18 & 64 \\
\hline
\end{tabular}

\begin{tabular}{|c|c|c|c|c|c|c|c|}
\hline $\begin{array}{l}\text { I like to be attentive and try } \\
\text { to pick up as much infor- } \\
\text { mation as I can }\end{array}$ & 4 & 0,6 & 0 & 0 & 4 & 32 & $\underline{64}$ \\
\hline $\begin{array}{l}\text { I am attracted to people from } \\
\text { different cultures as I find } \\
\text { them very interesting }\end{array}$ & 3 & 0,8 & 2 & 0 & 10 & 32 & 56 \\
\hline
\end{tabular}

It is also possible to see that $10 \%$ of teachers surveyed admit to feeling exasperated when they have to work or interact with people from other countries, the consequence of which being that they avoid situations involving intercultural contact.

With regards the second dimension raised by Chen and Starosta (2000), which refers to a respect for cultural differences (Table 3), it can be seen that teachers do not feel stress when interacting with people from other cultures (74\%), and that they in fact enjoy getting to know and learn from people who are culturally different (76\%). Also interesting is the oscillation of responses to this statement, indicating the need to be more alert when interacting with people from different cultures - even more so than when communicating with people from your own culture. Similarly, $10 \%$ of participants indicate that they do not enjoy working with people from other cultures.

Table 3. Descriptive "respecting cultural differences"

\begin{tabular}{|c|c|c|c|c|c|c|c|}
\hline Statement & $M$ & $S D$ & NS & SD & D & A & SA \\
\hline $\begin{array}{l}\text { I find it difficult to under- } \\
\text { stand people from other } \\
\text { cultures }\end{array}$ & 3 & 1,0 & 8 & 4 & 24 & 18 & 46 \\
\hline $\begin{array}{l}\text { I find it stressful to interact } \\
\text { with people from other } \\
\text { cultures }\end{array}$ & 4 & 0,9 & 2 & 4 & 4 & 16 & $\underline{74}$ \\
\hline $\begin{array}{l}\text { I do not like working with } \\
\text { people from different cul- } \\
\text { tures }\end{array}$ & 3 & 1,0 & $\underline{10}$ & 8 & 2 & 10 & 70 \\
\hline $\begin{array}{l}\text { I am more alert when inter- } \\
\text { acting with people from } \\
\text { different cultures }\end{array}$ & 2 & 1,0 & 4 & $\underline{22}$ & $\underline{28}$ & $\underline{32}$ & $\underline{14}$ \\
\hline $\begin{array}{l}\text { I like to meet and learn from } \\
\text { people from different cul- } \\
\text { tures }\end{array}$ & 4 & 0,4 & 0 & 0 & 0 & 24 & $\underline{76}$ \\
\hline $\begin{array}{l}\text { I find it harder to accept the } \\
\text { views of foreigners }\end{array}$ & 3 & 1,0 & 6 & 2 & 8 & 26 & $\underline{58}$ \\
\hline
\end{tabular}

Finally, it is important to note that $58 \%$ of teachers say that it is hard for them to accept the opinions of people from other cultures. Regarding the trust that must exist in a meeting between people from different cultures (Table 4), the results show that even though teachers think everyone's values are important (92\%) and feel sure of themselves (60\%), they are still uncomfortable interacting with people who are culturally different and find it hard to talk to them (56\%).

Table 4. Descriptions in "trust"

\begin{tabular}{lrrrrrrr}
\hline \multicolumn{1}{c}{ Statement } & $\boldsymbol{M}$ & $\boldsymbol{S D}$ & NS & SD & D & A & SA \\
\hline $\begin{array}{l}\text { I feel sure of myself when } \\
\text { interacting with foreigners }\end{array}$ & 4 & 0,7 & 0 & 4 & 2 & 34 & 60 \\
\hline $\begin{array}{l}\text { It is hard for me to talk to } \\
\text { people from other cultures }\end{array}$ & 3 & 1,0 & 4 & 4 & 18 & 18 & $\underline{56}$ \\
\hline $\begin{array}{l}\text { I believe that everyone's } \\
\text { values are important }\end{array}$ & 4 & 0,6 & 0 & 0 & 4 & 4 & $\underline{92}$ \\
\hline $\begin{array}{l}\text { I am more likely to feel } \\
\text { uncomfortable when interact- }\end{array}$ & 3 & 1,0 & 8 & 6 & 12 & 20 & $\underline{54}$ \\
\hline
\end{tabular}


ing with foreigner

\begin{tabular}{llllllll}
\hline I think that working with & 4 & 0,4 & 0 & 0 & 0 & 26 & 74
\end{tabular} people from different cul-

tures is very positive

$N S=$ Not Sure, $S D=$ Strongly Disagree, $D=$ Disagree, $A=$ Agree, $S A=$ Strongly Agree

Another of the factors inquired about was the level of enjoyment in the interaction (Table 5). In this scenario, the teachers declared themselves to be in total agreement: they are not driven by prejudice when they meet someone from another culture (38\%) and they exhibit a highly sociable attitude (72\%). A range of responses were obtained when subjects were asked about maintaining a more observant attitude with students from different cultures.

Table 5. Descriptives "extent to which you enjoy the interaction"

\begin{tabular}{|c|c|c|c|c|c|c|c|}
\hline Statement & $M$ & $S D$ & NS & SD & D & $\mathbf{A}$ & SA \\
\hline $\begin{array}{l}\text { I am equally sociable with } \\
\text { people from different cul- } \\
\text { tures }\end{array}$ & 4 & 1 & 6 & 2 & 2 & 18 & 72 \\
\hline $\begin{array}{l}\text { When I meet someone from } \\
\text { another culture I try not to go } \\
\text { by what others tell me }\end{array}$ & 3 & 1 & & 14 & 18 & $\underline{30}$ & $\underline{38}$ \\
\hline $\begin{array}{l}\text { I am more observant when } \\
\text { interacting with people from } \\
\text { other cultures }\end{array}$ & 2 & 1 & 6 & $\underline{16}$ & $\underline{22}$ & $\underline{36}$ & 20 \\
\hline
\end{tabular}

The last factor raised the question of how much attention is paid during interaction (Table 6). It can be seen that a high percentage of teachers do not trust in their abilities to communicate with foreigners $(50 \%)$, despite considering themselves to be open minded (80\%).

Table 6. Descriptives “attention during interaction”

\begin{tabular}{|c|c|c|c|c|c|c|c|}
\hline Statement & $M$ & $S D$ & NS & SD & D & $\mathbf{A}$ & SA \\
\hline $\begin{array}{l}\text { I consider myself to be open } \\
\text { minded about cultural differ- } \\
\text { ences }\end{array}$ & 4 & 0,6 & 0 & 2 & 0 & 18 & $\underline{80}$ \\
\hline $\begin{array}{l}\text { I do not trust in my ability to } \\
\text { communicate with foreigners }\end{array}$ & 3 & 1,0 & 8 & 2 & 12 & 28 & 50 \\
\hline $\begin{array}{l}\text { When I speak to someone } \\
\text { from another culture I make } \\
\text { an effort to show that I } \\
\text { understand }\end{array}$ & 3 & 0,8 & 0 & 4 & 8 & 38 & $\underline{50}$ \\
\hline
\end{tabular}

In addition, a high percentage (50\%) of teachers stated that when talking with a person from a different culture, they try to show that they understand the person.

Table 8. Differences in intercultural sensitivity by age
Regarding the comparison of groups based on gender, age, training and intercultural experience of teachers, we can conclude that no statistically significant differences were found in relation to intercultural sensitivity, especially in the areas of experience and training. Perhaps this can be explained by the low percentage of teachers who have received specific cultural training in the area of intercultural education (12\%) and by the homogeneity of the professional profile characterized by working in multicultural contexts (92\%) with levels of immigrant students. Below, we outline the statements that elicited the most statistically significant differences in the variables of gender and age of teachers (Tables 7 and 8).

Table 7. Differences in intercultural sensitivity between genders

\begin{tabular}{|c|c|c|c|c|c|c|}
\hline Statement & 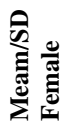 & 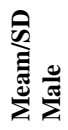 & $\mathbf{T}$ & $g l$ & $p$ & \\
\hline $\begin{array}{l}\text { I'm more ob- } \\
\text { servant when } \\
\text { interacting with } \\
\text { people from other } \\
\text { cultures }\end{array}$ & $\begin{array}{c}2,3 / \\
1,2\end{array}$ & $\begin{array}{c}2,9 / \\
, 96\end{array}$ & $-2,019$ & 3,027 & 0,05 & $\mathrm{M}<\mathrm{H}$ \\
\hline $\begin{array}{l}\text { I am more alert } \\
\text { when interacting } \\
\text { with people from } \\
\text { different cultures }\end{array}$ & $\begin{array}{c}2,1 / \\
1,1\end{array}$ & $\begin{array}{c}2,8 / \\
, 86\end{array}$ & $-2,444$ & 3,027 & 0,02 & $\mathrm{M}<\mathrm{H}$ \\
\hline
\end{tabular}

Overall, there are no statistically significant differences. Between the genders, however, the differences manifest themselves in male teachers [ $t(3,027)=-2,019 ; \mathrm{p}=, 052]$, who reveal themselves as having a more observant attitude when interacting with people from different cultures and being more alert when approaching intercultural contact $[\mathrm{t}(3,027)=-2,444$; $\mathrm{p}=, 020]$.

The results show that teachers over the age of 50 find it harder to accept the opinions of foreigners [F $(4,265)=2,76$; $p=, 053]$.

\section{CONCLUSION}

To place the findings into the conceptual framework underpinning this research, we can present the following figure:

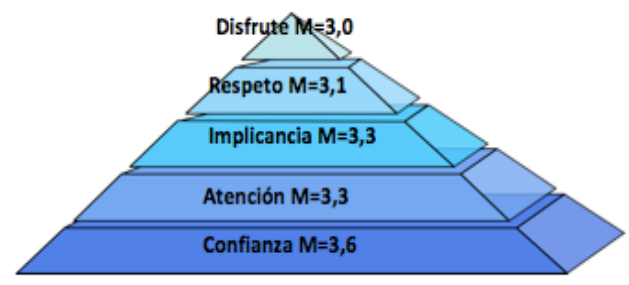

Figure 1. Factors that constitute intercultural sensitivity

Source: Prepared by the authors from results obtained following the model of Chen \& Starosta (2000).

\begin{tabular}{|c|c|c|c|c|c|c|c|c|}
\hline \multirow[t]{2}{*}{ Statement } & \multicolumn{4}{|c|}{ Age } & \multirow[t]{2}{*}{$\mathbf{F}$} & \multirow[t]{2}{*}{$g l$} & \multirow[t]{2}{*}{$p$} & \multirow[t]{2}{*}{ Direcction } \\
\hline & $\begin{array}{l}\text { Mean/SD } \\
20-29 \text { years } \\
\text { old }\end{array}$ & $\begin{array}{c}\text { Mean/SD } \\
\text { 30-39 years } \\
\text { old }\end{array}$ & $\begin{array}{c}\text { Mean/SD } \\
40-49 \text { years } \\
\text { old }\end{array}$ & $\begin{array}{c}\text { Mean/SD } \\
\text { Over } 50 \\
\text { years old }\end{array}$ & & & & \\
\hline $\begin{array}{l}\text { I become exasperated when dealing with } \\
\text { people who are culturally different }\end{array}$ & $2,2 / 1,7$ & $3,9 / 0,3$ & $2,8 / 1,8$ & $3,7 / 0,6$ & 4,24 & 4,265 & 0,01 & $\mathrm{E} 1, \mathrm{E} 3, \mathrm{E} 4<\mathrm{E} 2$ \\
\hline $\begin{array}{l}\text { I find it difficult to accept the opinions of } \\
\text { people who are culturally different }\end{array}$ & $2,4 / 1,6$ & $3,5 / 0,5$ & $3,2 / 1,3$ & $3,6 / 0,7$ & 2,76 & 4,265 & 0,05 & $\mathrm{E} 1, \mathrm{E} 2, \mathrm{E} 3<\mathrm{E} 4$ \\
\hline
\end{tabular}


Chen and Starosta (2000) conceptualize the emotional component of intercultural communication as intercultural sensitivity. This dimension is focused on personal emotions or changes in feelings caused by culturally diverse situations, people or environments. The components of intercultural sensitivity would be trust, implication, attention and the capacity to enjoy intercultural interaction. As noted in the Method section, the Likert scale has 5 points. The means obtained for teachers range between 3 and 4 points, indicating, in general terms, a positive but moderate level of intercultural sensitivity. These results can be confirmed by adding up the final score obtained by teachers: 85 points (Osma et al., 2010). This response is characterised by an attitude of respect and acceptance towards cultural differences but it does not involve an assessment of these differences. The teachers can "accept" cultural diversity, but they fail to modify the structure, operation and pedagogical approach of their classes to guarantee each student success in learning. A change in the mentality of teachers implies an understanding that both native and immigrant students would benefit from an education that recognises and values cultural diversity.

In the same vein, Norambuena (2013) carried out a study to analyse the integration of immigrants in Chile, reaching a conclusion that the country is neither xenophobic, nor particularly welcoming, merely receptive. Therefore, it seems that the emotional answers of the teachers in this research are still marginal. The teachers obtained higher scores for trust, and lower scores for enjoyment of interaction and respect for differences, evidencing difficulties in understanding people from other cultures and accepting their opinions. Regarding previous research, the results obtained on the factor of trust are opposite to those reported in the literature (Vilà, 2010; Sanhueza, Quintriqueo, \& Friz, 2014) which show this competence to be the most difficult to achieve, at least with students.

Moreover, if we consider that $92 \%$ of participants stated that they had experience working with immigrant children, we can infer that mere contact does not imply learning or the change in social practices that is an intrinsic aspect of intercultural phenomenon. Indeed, as we mention in the theoretical framework, previous studies indicate that one variable which has a positive effect on intercultural sensitivity is experience (Sanhueza \& Cardona, 2009; Sanhueza et al., 2014). However, our results warn us that not all experience favours a positive emotional response, and so teachers should carefully plan the strategies they will put into practice to achieve effective communication in the classroom. From our point of view, this will only happen if different cultures interact from a basic principle of right to diversity and if both natives and immigrants are open to mutual recognition.

When we analyse the differences in intercultural sensitivity according to gender, the results indicate that men are more attentive $(p=0.02)$ and observant $(p=0.05)$ when it comes to establishing a relationship with people from a different culture. Until now, studies had revealed greater sensitivity in women, and therefore the results show progress in this area, at least in the competencies indicated.

Differences were also found in the age variable. Younger teachers seem not to become as exasperated when dealing with culturally different people, while teachers over 50 admit that they find it hard to accept the opinions of such people. This result could be explained by contextual variables, since -as immigration is new to Chile- older teachers are not trained, at least intentionally in the curriculum, to address cultural diversity
(Sanhueza, Paukner, \& San Martín, 2012). Nonetheless, in the last five years, the Ministerio de Educación de Chile has devoted significant resources to strengthening initial teacher training, thereby promoting the design of complementary plans to address issues such as the education of citizens, harmonious relations in schools, and cultural diversity. An enabling environment for the incorporation of these themes has been provided by the Objetivos Fundamentales Transversales (OFT); initial pedagogical practices; and "attention to diversity" courses, among other aspects. While these efforts have been a major impetus behind the elimination of stereotypes and prejudices, they are insufficient in that the majority of cases are considered "optional" or "complementary" and do not therefore permeate the teacher training curriculum in a more mainstream way.

The comparative analysis of advanced training and intercultural experience did not yield any significant statistical differences regarding intercultural sensitivity and have therefore been omitted from the article. However, training and contact are key to an adequate future professional development in contexts of diversity. Vásquez, Fernández and Álvarez (2014) indicate that training does make a difference in teaching, as well as in interaction with people of different cultural backgrounds, particularly in terms of professional intervention, respect, enjoyment of interaction among other areas.

As we have seen, the emotional skills involved in intercultural communicative competency (respect, appreciation, empathy, acceptance) are the cornerstone for the promotion of inclusive schools, hence the need for teachers to be trained in this area.

We recommend that future research go deeper into aspects of intercultural education using a qualitative methodology, with the aim of expanding the results of our survey. The study is limited in terms of the sample, declared as intentional and subject to availability (Cardona, 2002), so we suggest that subsequent studies increase the number of participants in order to achieve greater representation. Generalizations that may be drawn from the results of this study remain limited to the sample presented and/or samples with similar characteristics.

The results provide interesting educational implications. These include the need to work on techniques that are conducive to trust and empathy between teachers and students; the establishing of permanent teacher training programmes on intercultural communication; the provision of competencies for planning effective pedagogical strategies (since as the results show, mere contact does not guarantee better communication); the promotion of a focus of attention on cultural diversity based on human rights; and the recognition of cultural minorities within the classroom, among other measures.

\section{TRANSFER INTO PRACTICE}

Migratory processes constitute a global phenomenon that makes the social and economic inequalities of different countries very evident. In the particular case of Latin America, thousands of people cross its borders every day, posing new challenges, such as the provision of homes to children, young people and their families; as well as the granting of access to education, healthcare, work and a dignified life.

In terms of education, the results of the article suggest it would be advisable to improve the training curriculums of future teachers by integrating the theme of cultural diversity explicitly and transversally into the different degrees - via the design and implementation of programmes for development of intercultural communication for example. 


\section{ACKNOWLEDGEMENTS}

Funded by: Comisión Nacional de Investigación Científica y Tecnológica de Chile

Funder Identifier: http://dx.doi.org/10.13039/501100002847

Award: FONDECYT Nº 1140864; ANILLOS SOC 1401

The article is part of Proyectos FONDECYT $\mathrm{N}^{\circ} 1140864$ Desarrollo de la Competencia Comunicativa Intercultural (CCI) en estudiantes universitarios de las regiones del Maule, Bío-Bío y La Araucanía and ANILLOS SOC 1401 Inmigrantes en el sistema educacional de Chile. Representaciones de género, lengua, territorialidad y exclusión social, funded by the Comisión Nacional de Investigación Científica y Tecnológica de Chile.

\section{REFERENCES}

Alonso, M., \& Martínez, C. (2011). Educación multicultural y bienestar social del profesorado. Revista Argentina de Ciencias del Comportamiento, 3(3), 32-37.

Alvites, L., \& Jiménez, A. (2011). Niños y niñas migrantes, desafío pendiente. Synergies Chili, 7, 121-136.

Barra, N. (2007). El desafío de la diversidad cultural para Chile (Technical Report). Arlington, Massachusetts: Intercultural Center for Research in Education.

Calatayud, M. A. (2006). Formación en educación intercultural: la voz del profesorado. Aula Abierta, 88, 73-84.

Cardona, M. C. (2002). Introducción a los métodos de investigación en educación. Madrid: EOS.

Chen, G., \& Starosta, W. (2000). The development and validation of the intercultural sensitivity scale. Human Communication, 2(1), 27-54.

Chiner, E., Cardona, M. C., \& Gómez, J. (2015). Teachers’ beliefs about diversity: an analysis from a personal and professional perspective. Journal of New Approaches in Educational Research, 4(1), 18-23. doi:10.7821/naer.2015.1.113

Díaz-Aguado, M. (2006). Educación intercultural y aprendizaje cooperative. Madrid: Pirámide.

García, J. (2005). Educación Intercultural: Análisis y propuestas. Revista de Educación, 336(1), 89-109.

Hernández, R., Fernández, C., \& Baptista, M. (2010). Fundamentos de metodología de la investigación. México: McGraw Hill.

McCroskey, J., \& Neuliep, J. (1997). The development of intercultural and interethnic communication apprehension scales. Communication Research Reports, 14(2), 145-156. doi:10.1080/08824099709388656

Medina, A., \& Domínguez, C. (2006). La formación del profesorado ante los nuevos retos de la interculturalidad. In A. Medina, A. Rodríguez \& A. Ibáñez (Eds.), Interculturalidad. Formación del profesorado y educación (pp. 13-27). Madrid: Pearson Prentice Hall.

Medina, A., Rodríguez, A., \& Ibáñez, A. (2004) Interculturalidad: formación del profesorado y Educación. Madrid: Pearson Educación.

Ministerio de Educación (2014). Estadística oficial de matrícula alumnado extranjero en establecimientos municipales de Chile (Technical Report). Santiago: Línea 600.

Ministerio del Interior de Chile (2015). Informe de estadísticas de inmigración en Chile (Technical Report). Santiago de Chile.

Norambuena, C. (2013). Amenazas sin fronteras: nuevas periferias en la circulación de personas. Cuadernos de Historia, 39, 147-168. doi:10.4067/S071912432013000200006

Osma, J., Crespo, E., \& Fermoselle, E. (2010). Evaluación de la sensibilidad intercultural en la Universitat Jaume I: datos preliminares sobre una muestra de jóvenes estudiantes. Castellón: Universitat Jaume I.

Quintriqueo, S., Quilaqueo, D., Lepe, P., Riquelme, E., Gutiérrez, M., \& Peña, F. (2014). Formación del profesorado en educación intercultural en América Latina. El caso de Chile. Revista Electrónica Interuniversitaria de Formación del Profesorado, 2(17), 201-217.

Sanhueza, S. (2010). Sensibilidad intercultural: un estudio exploratorio con alumnado de educación primaria y secundaria en la provincia de alicante. (Doctoral dissertation). University of Alicante, Alicante.

Sanhueza, S., \& Cardona, M.C. (2009). Sensibilidad Intercultural de alumnado escolarizado en aulas culturalmente diversas. Revista de Investigación Educativa RIE, 27(1), 247-262.

Sanhueza, S., Cardona, M.C., \& Friz, M. (2015). Understanding elementary and secondary students representation of cultural differences as reflected in the process of intercultural communication in school contexts. Nordic Psychology, 67(1), 65-86 doi:10.1080/19012276.2014.997785
Sanhueza, S., Granada, M., \& Bravo, L. (2012). Actitudes del profesorado de Chile y Costa Rica hacia la inclusión educativa. Cadernos de Pesquisa, 42(147), 884899. doi:10.1590/S0100-15742012000300013

Sanhueza, S., Quintriqueo, S., \& Friz, M. (2014). Estudio exploratorio sobre las actitudes y comportamiento del profesorado de Chile en contextos de escolarización de alumnado inmigrante. Revista Electrónica de Investigación Educativa REDIE, 16(3), 38-57.

Sanhueza, S., Paukner, F., San Martín, V., \& Friz, M. (2012). Dimensiones de la competencia comunicativa intercultural (CCI) y sus implicaciones para la práctica educative. FOLIOS, 36, 131-151. doi: 10.17227/01234870.36folios131.151

Stefoni, C. (2011). Perfil migratorio de Chile (Technical Report). Argentina: Organización Internacional para las Migraciones.

Vásquez, O., Fernández, M., \& Álvarez, P. (2014). La aportación de los grados al desarrollo de la sensibilidad y competencia intercultural. Perspectiva comparada entre Trabajo Social y Psicología. Cuadernos de Trabajo Social, 27(2), 307317.

Vilà, R. (2005). La competencia comunicativa intercultural. Un estudio en el primer ciclo de la ESO (Doctoral Dissertation). University of Barcelona, Barcelona.

Vilà, R. (2010). La competencia comunicativa intercultural en alumnos de Enseñanza Secundaria de Catalunya. Revista Electrónica de investigación y didáctica, 3, 88-108.

\section{How to cite this article:}

Morales, K.; Sanhueza, S; Friz, M.; Riquelme, P. (2017). The Intercultural Sensitivity of Chilean Teachers Serving an Immigrant Population in Schools. Journal of New Approaches in Educational Research, 6(1), 71-77. doi: 10.7821/naer.2016.8.173 